\section{Р.В. Соболевський, д.т.н., проф. С.С. Іськов, к.т.н., доц. \\ О.В. Камських, к.т.н., доц. I.В. Леонець, магістр \\ Державний університет «Житомирська політехніка»}

О.О. Шустов, к.т.н.

Національний технічний університет «Дніпровська політехніка»

\title{
Врахування анізотропії структурних показників покладів декоративного каменю під час вибору раціонального напряму розвитку гірничих робіт
}

\begin{abstract}
Наведено результати досліджень щзодо перспективності врахування анізотропіі структурних показників покладів декоративного каменю під час вибору раціонального напряму розвитку гірничих робіт. Досліджено публікачії, які присвячені вивченню закономірностей формування покладів декоративного каменю. Вивчено підходи щзодо дослідження та врахування анізотропії технологічних властивостей покладів і окремих ділянок декоративно-облицювального каменю. Розроблено методику оперативного визначення вмісту та орієнтації зерен мінералів на основі обробки циифрового зображення поверхні декоративного каменю, яке одержано під час використання цифрового мікроскопа. Вивчено закономірності просторової мінливості напрямків оптимального відколу для родовищ лабрадоритів та габро-норитів. Встановлено аналітичну залежність у вигляді полінома четвертого ступеня для прогнозування оптимального напрямку відколу для Головинського родовища лабрадориту та доведено відсутність зв'язку оптимального напрямку відколу й орієнтації тріщцинватості для Сліпчищького родовища габро-нориту. Закладено основні елементи для розробки оптимальної методики оперативного планування гірничих робіт із урахуванням анізотропії властивостей покладу декоративного каменю різного генезису. Результати одержаних досліджень дають змогу розробити оптимальну методику планування зазначених гірничих робіт.
\end{abstract}

Ключові слова: анізотропія; декоративний камінь; тріщинуватість; блочність; орієнтування фронту видобувних робіт.

Постановка проблеми та їі зв'язок із важливими практичними завданнями. Під час розробки родовищ декоративно-облицювального каменю економічна ефективність видобування значною мірою залежатиме від ефективності управління технологічними процесами. Згідно з результатами досліджень підходів до процесу видобування блоків декоративного каменю [1-8], ефективність використання окремих технологічних процесів та продуктивність усього комплексу видобувного обладнання визначаються як природними, так і технологічними показниками. Слід зазначити, що серед природних чинників найбільш суттєво на ефективність видобування блоків впливає тріщинуватість. Під час планування гірничих робіт необхідно забезпечити максимальне врахування просторової орієнтації та відстаней між площинами тріщин. Ці фактори визначають параметри системи розробки покладу, тому помилка їх оцінки потенційно може призвести до значних економічних втрат, що підкреслює важливість правильного вибору методу аналізу.

Для систематизації природної тріщинуватості використовуються різноманітні методи, які відрізняються своєю ефективністю та достовірністю, які значною мірою визначаються ступенем врахування анізотропності масиву покладу блочної сировини. Тому можна вважати, що врахування анізотропії структурних показників покладів декоративного каменю при виборі раціонального напряму розвитку гірничих робіт дозволить підвищити ефективність процесу управління якістю блочної сировини.

Аналіз останніх досліджень і публікацій. Достовірна інформація про закономірності розвитку тріщинуватості покладу дозволить забезпечити високу ефективність управління якістю за рахунок оптимізації параметрів буровибухових робіт, визначення оптимальних розмірів моноліту, оцінки блочності скельних масивів, оцінки впливу тріщинуватості на ефективність окремих технологічних процесів.

Під час аналізу ефективності управління процесом видобування блочного каменю застосовувалися різні підходи. Так в [1] розглянуто питання оптимізації планування роботи технологічного комплексу. Інші автори оцінювали ефективність управління за ступенем врахування параметрів тріщинуватості покладу [2-6]. Причому, особливу увагу приділено методиці вимірювання елементів тріщин. У [2] досліджено ефективність визначення параметрів тріщинуватості під час використання георадара (GPR) та іï̈ вплив на якість масиву природнього каменю. В [3] досліджено вплив природньої тріщінуватості на продуктивність технологічних комплексів. Можна виокремити групу робіт [4-11], основним завданням яких була оцінка блочності покладів декоративного каменю. Ця низка публікацій характеризується різноманітністю підходів до визначення блочності, що частково зумовлено різними типами порід, для яких проводилися дослідження. У $[4,5]$ велику увагу приділено оцінці блочності на основі аналізу геометричних співвідношень між системами тріщин. 
Дослідження впливу тріщинуватості на якість покладу декоративного каменю вивчалася в [6-11]. У [6] досліджено методику оцінки покладу декоративного каменю для одержання блочної продукції на основі результатів заміру тріщінуватості. У [7] виконано оцінку якості покладу для високоблочних родовищ мармуру. У [8] на основі моделювання систем тріщин та розривів оцінено блочність покладу, причому, особливістю $\epsilon$ використання кубів замість класичних паралелепіпедів для моделі штучного блоку. У [9] виконано геостатистичне моделювання ефективності видобування блочного каменю за допомогою різання, що суттєво звужує сферу застосування результатів цього дослідження, і потребує подальшого комплексного врахування впливу інших технологій під час планування розвитку гірничих робіт У [10] виконано оцінку економічної ефективності видобування блоків при різних підходах до орієнтації фронту робіт. У раніше виконаних дослідженнях впливу природних факторів на ефективність розробки покладу декоративного каменю [11] використовувалася оцінка якості покладу на основі застосування дистанційних методів вивчення тріщінуватості та математичного моделювання ефективності розкроювання одержаної моделі природної окремості залежно від обраного напряму розвитку гірничих робіт.

У результаті виконаних досліджень було доведено, що тріщинуватість масиву може впливати на продуктивність процесу буріння [12], що дає можливість реалізувати процес управління якістю нерудних будівельних матеріалів на основі вибору оптимальних значень технологічних параметрів процесу буріння.

Результати досліджень публікацій $[9,10,13]$ свідчать, що напрямок найкращого розколювання каменю значною мірою залежить від структурно-текстурної будови порід, яка оцінюється на основі аналізу шліфів у поляризованому світлі. Такий підхід досить працемісткий і не дозволяє оперативно оцінити необхідні параметри. Альтернативою такому методу слід розглядати метод, запропонований у [10], який містить ідею сканування зображення поверхні гірської породи та обробки даних за допомогою комп’ютерних технологій, при цьому співвідношення між поперечними розмірами кристалів визначає анізотропність породи.

Підсумовуючи публікації щодо визначення напряму розвитку гірничих робіт на родовищах блочного каменю, можна зробити висновок, що тріщинуватість покладу є домінуючим показником його якості та значною мірою визначає напрям розвитку гірничих робіт і структуру комплексної механізації видобувних процесів. Тому врахування анізотропії структурних показників покладів декоративного каменю під час вибору раціонального напряму розвитку гірничих робіт є актуальним науково-прикладним завданням.

Мета та завдання дослідження. Мета роботи полягає у дослідженні підходів щодо обгрунтування раціонального напряму розвитку гірничих робіт на основі врахування анізотропії структурних показників.

Для досягнення мети у статті визначено такі завдання:

1) виконати розробку методики оперативного визначення вмісту та орієнтації зерен мінералів на основі виконання вимірювань цифровим мікроскопом;

2) дослідити закономірності просторової мінливості напрямків оптимального відколу для родовищ лабрадоритів та габро-норитів;

3) одержати аналітичні залежності для прогнозування оптимального напрямку відколу.

Матеріали та методи дослідження. Методику оперативного визначення вмісту й орієнтації зерен мінералів розроблено на основі використання вимірювань цифровим мікроскопом S07-500X. Алгоритм визначення основних закономірностей орієнтації зерен плагіоклазу в габроїдних породах на основі використання цього приладу наведено на рисунку 1.

Одержання зображення за допомогою цифрового мікроскопу в трьох точках на уступі в масиві габро через кожні 5 м

Калібрування зображення відповідно до відстані між об'єктивом цифрового мікроскопа та масивом

Накладання маски за методом Оцу відповідно до оптимальних параметрів, які були підібрані для цього родовиша Одержання маски

Одержання графіка розподілу зерен мінералів, значень середнього розміру зерна для цього зображення (1)

Рис. 1. Алгоритм визначення основних закономірностей орієнтащії зерен плагіоклазу в габроїднх породах 
Реалізація запропонованого алгоритму для визначення орієнтації зерен основних мінералів виконана в програмному продукті з вільним кодом Gwiddeon. Приклад його використання для обробки зображення наведено на рисунку 2.
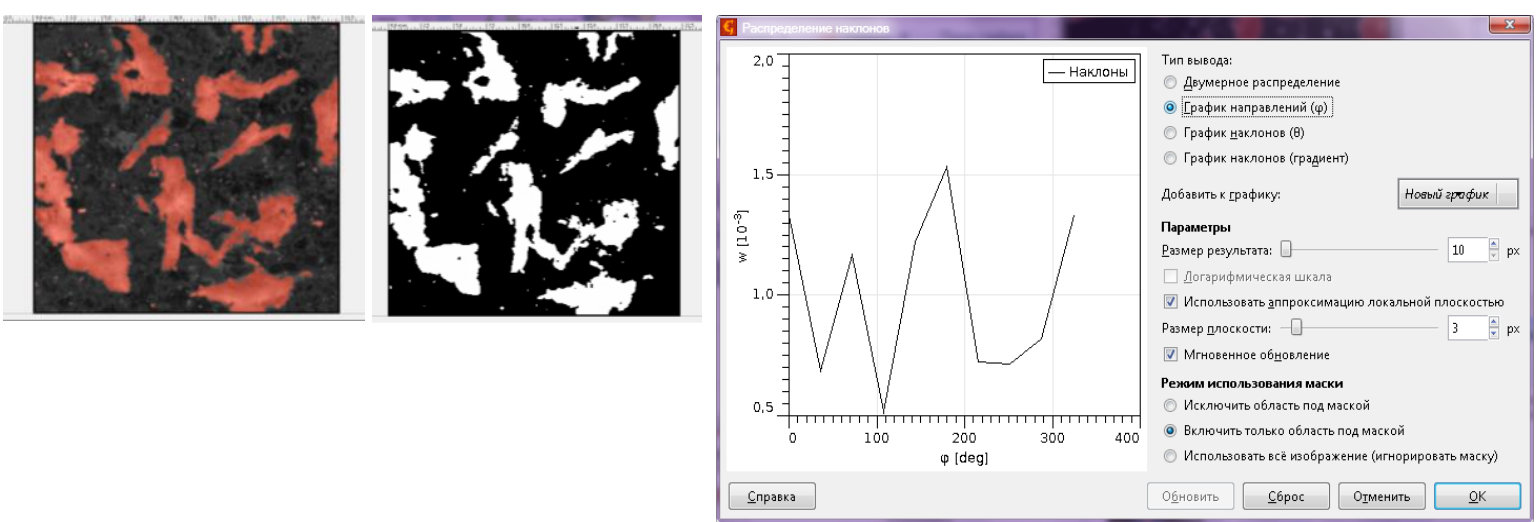

Рис. 2. Визначення орієнтачї мінералів

Геопросторовий аналіз анізотропії властивостей декоративного каменю виконано на основі результатів петрографічного i мікроструктурного вивчення орієнтованих монолітів порід, безпосереднього вимірювання орієнтації тріщин у масиві за допомогою цифрового мікроскопа в стінках Сліпчицького та Головинського кар'єрів. Для геопросторової оцінки тріщинуватості було попередньо оцифровано картографічні матеріали, на які нанесено місця відбору проб і заміру тріщин (рис. 3-4) та введено місцеву систему координат на основі прив'язки до характерних об'єктів.

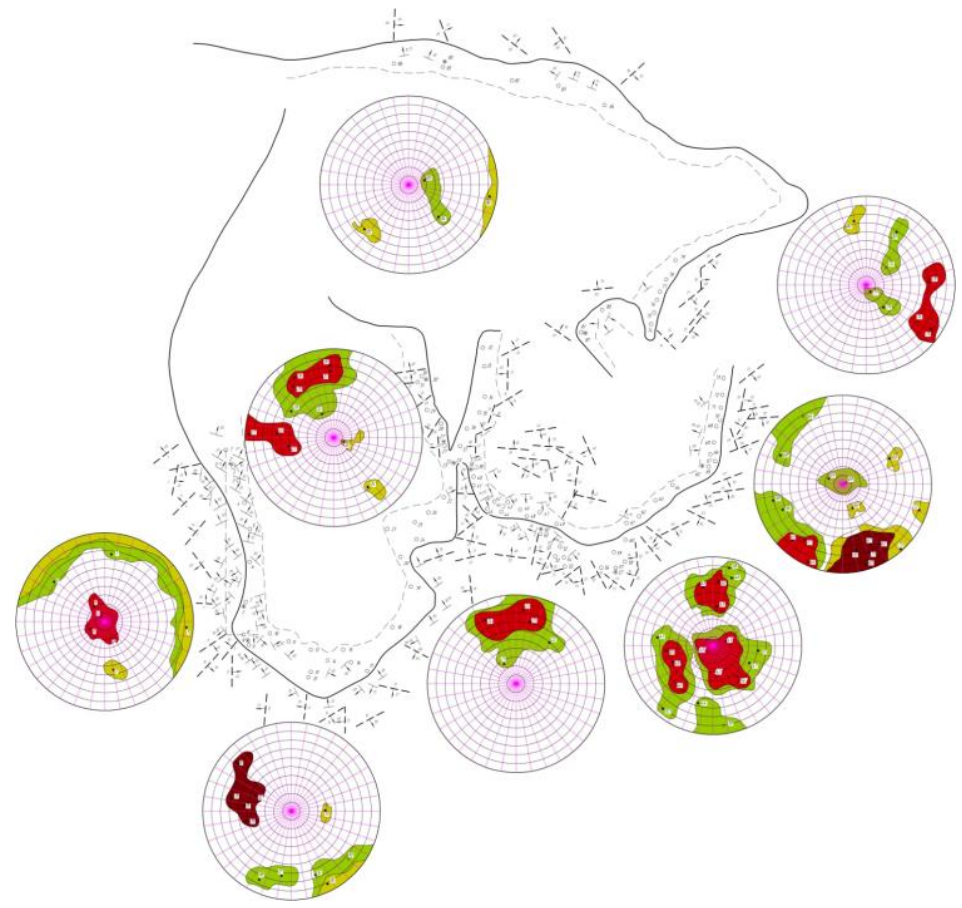

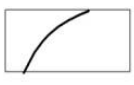

Мехі кロD'EPQ

Точкова діаграма тріщинцваптості 3 iзолініяMU.

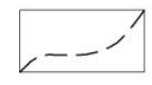

Умовна меха розвапу габро-нориттів กï0wBu ycmyna

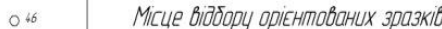
монолітів Әпя мікрострукКтурного анапізу.

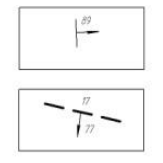

гередні елементи залягання макросторуктурних тріщин.

Рекомендованиі напряммк вїриви монопітов згібно результпатів мікроструктпурного аналізу.

Рис. 3. Рекомендовані напрямки відколу монолітних блоків за даними мікроструктурного аналізу та елементи залягання тріщин для Сліпчщщького родовища габро-нориту 


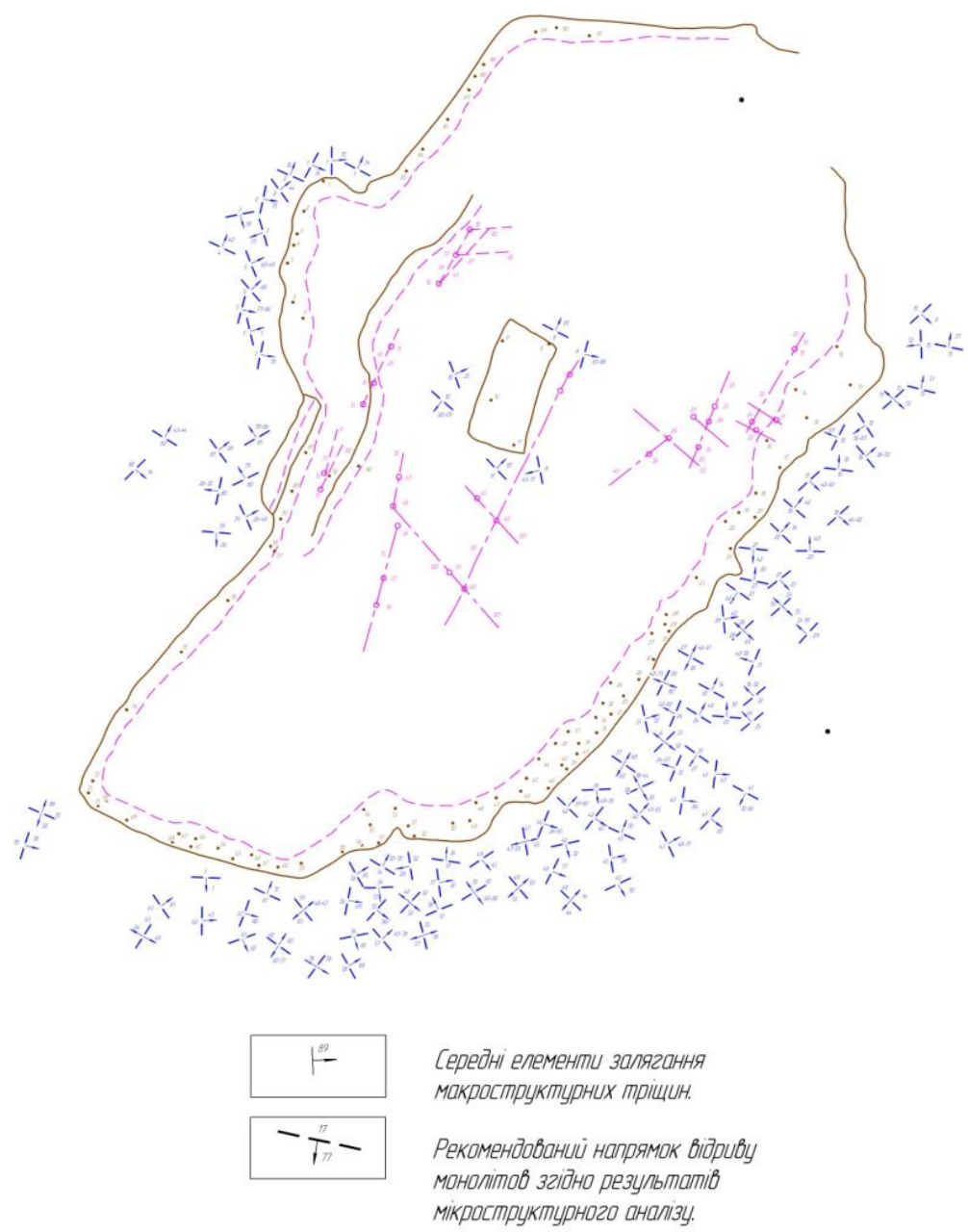

Рис. 4. Рекомендовані напрямки відколу монолітних блоків за даними мікроструктурного аналізу та елементи залягання тріщин для Головинського лабрадориту

Викладення основного матеріалу. Усі попередні дослідження тріщинуватості свідчать, що на родовищах магматичних порід існує закономірна система тріщин - це зайвий раз вказує на анізотропію інтрузивних масивів. На першому етапі досліджень було вивчено просторову мінливість напрямку протікання магми під час формування родовища на основі гіпотези [7, 12] про відповідність напрямку повздовжньої системи тріщин до напрямків протікання магми. 3 цією метою було визначено орієнтацію тріщин у масиві та їх просторове положення за результатами встановленого положення окремих тріщин на картах тріщинуватості і безпосереднього вимірювання окремих тріщин у масиві. Одержані дані дали можливість побудувати вектори зміни напрямків орієнтації окремих тріщин, які при інтерполюванні дають можливість спрогнозувати напрямки протікання магми в період формування родовища (рис. 5).

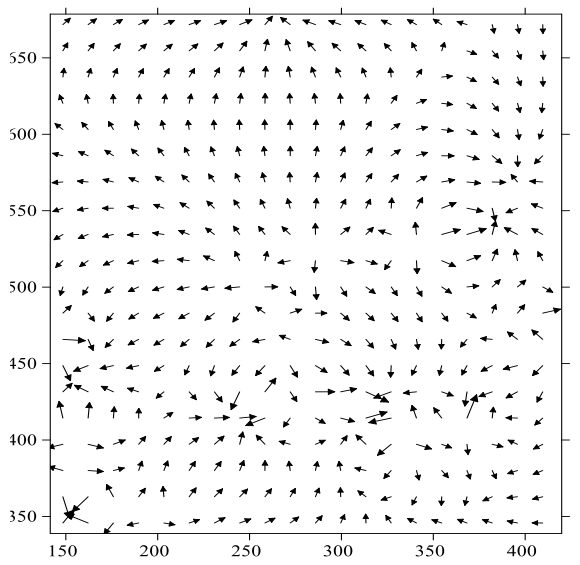

Рис. 5. Модель напрямків протікання магми для Сліпчицького родовища габро-нориту 
Зіставлення одержаної моделі напрямків протікання магми для Сліпчицького родовища габро-нориту зі структурно-текстурною будовою (рис. 6) свідчить про закономірне розташування мінералів, орієнтація яких підпорядкована основним векторам руху магми.

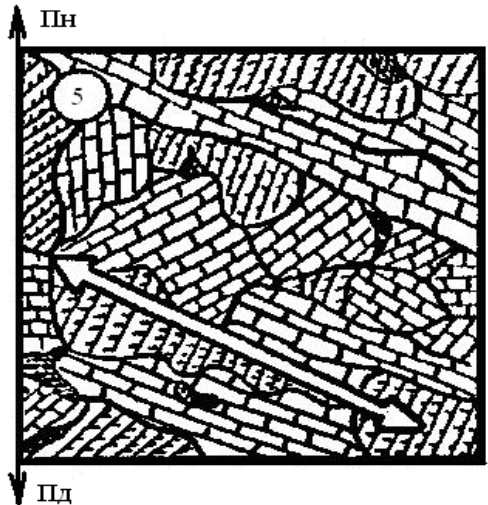

$a$

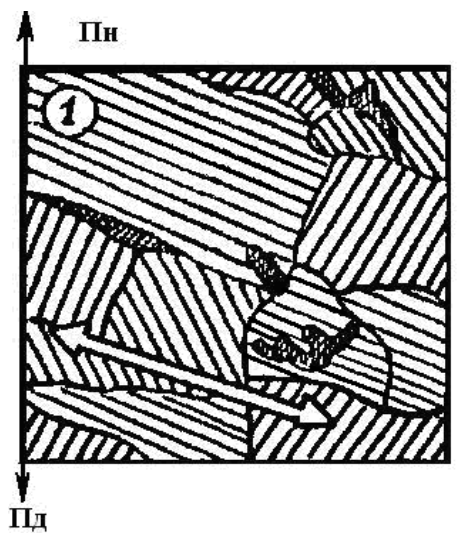

$\sigma$

Рис. 6. Структурно-текстурна будова габроїдних порід [5]: а-Сліпчицького габро-нориту; б - Головинського лабрадориту

За результатами проведених робіт було розроблено таблиці, у яких зведено рекомендований напрямок відколу монолітних блоків та елементи залягання природних тріщин. Для габро-норитів Сліпчицького родовища аналіз взаємозв'язку рекомендованого напрямку відколу з азимутом простягання 86 тріщин (рис. 7) встановив наявність слабкого кореляційного зв'язку, який характеризується коефіцієнтом кореляції 0,14.

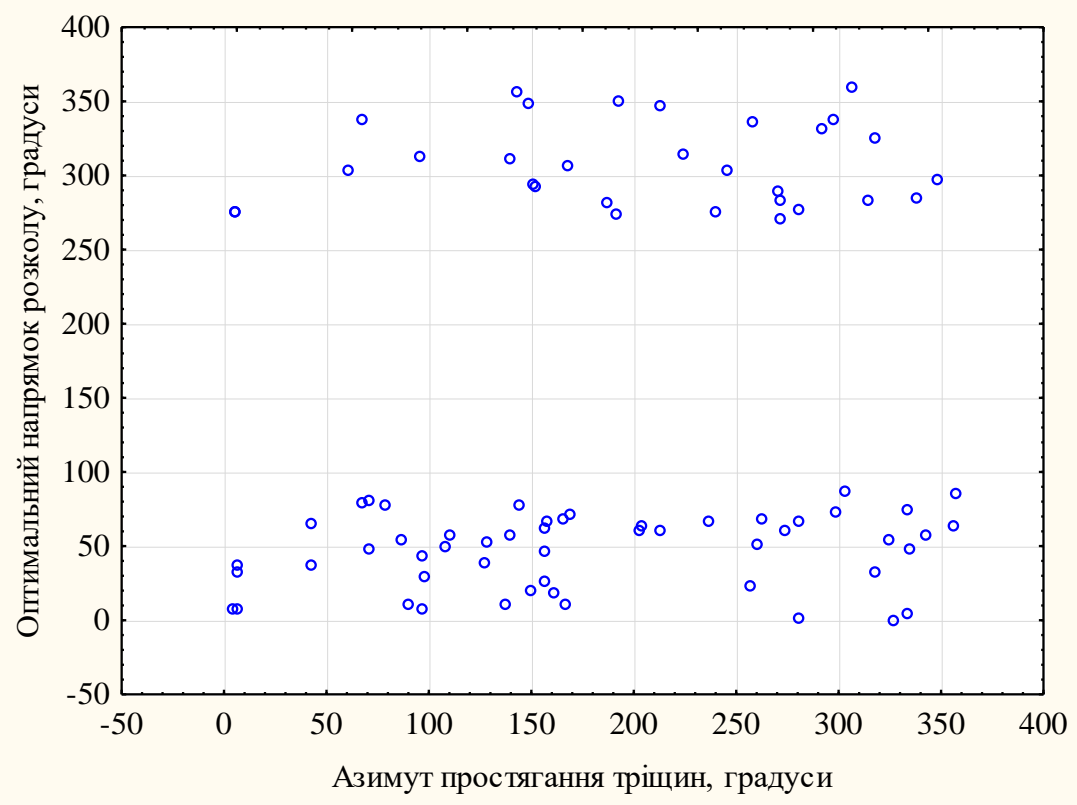

Рис. 7. Кореляиійне поле для оптимального напрямку розколу та азимуту простягання тріщин

Геопросторова оцінка співвідношення напрямків оптимального відколу з азимутами падіння тріщин, що виконано на основі побудови карти векторів (рис. 8), дає можливість виявити окремі ділянки, для яких характерний певний взаємозв'язок між орієнтацією тріщин і оптимальним напрямком відколу. Особливо яскраво це виражено у східній частині родовища. Але можна констатувати, що в цілому по родовищу взаємозв'язок відсутній. Під час подальших досліджень було виконано групування тріщин (табл. 1), що дало змогу встановити наявність тісного кореляційного зв'язку для повздовжніх тріщин (коефіцієнт кореляції 0,35$)$ та слабкого кореляційного зв'язку для поперечних $(0,14)$, субгоризонтальних $(0,19)$ i пластових $(0,17)$ тріщин, що дає підставу дійти до висновку, що для Сліпчицького родовища габро-норитів відсутній взаємозв'язок між орієнтацією тріщинуватості та оптимальним напрямком відколу. 


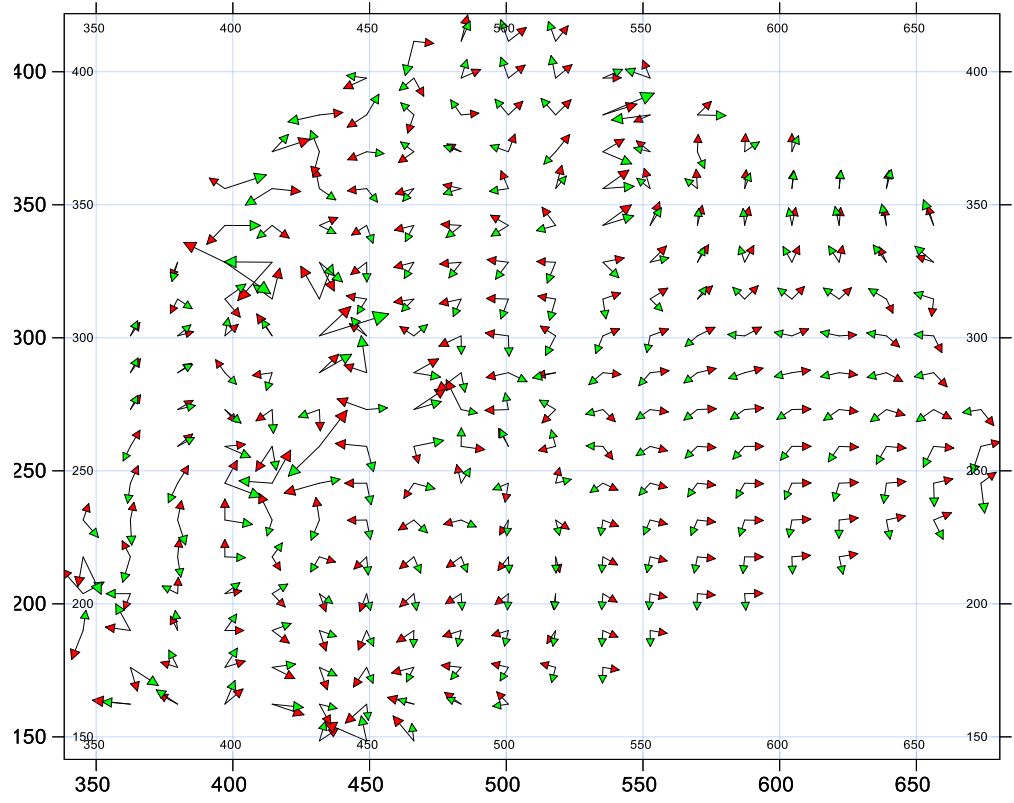

Рис. 8. Співвідношення напрямків оптимального відколу з азимутами падіння тріщин (червоний - напрямок тріщин, зелений - напрямок відколу)

Таблиия 1

Результати виокремлення систем тріщинуватості для Сліпчищького родовища габро-норитів

\begin{tabular}{|c|c|c|c|c|}
\hline Показник & 1 система & 2 система & 3 система & 4 система \\
\hline Мінімальне значення, градуси & 292,0000 & 108,0000 & 4,00000 & 203,0000 \\
\hline Максимальне значення, градуси & 357,0000 & 193,0000 & 98,00000 & 281,0000 \\
\hline Середнє значення & 324,6111 & 152,2800 & 54,90000 & 249,7368 \\
\hline Дисперсія, градуси & 20,0445 & 21,5320 & 36,74793 & 27,0079 \\
\hline Питома частка, відсотки & 21,95122 & 30,48780 & 24,39024 & 23,17073 \\
\hline
\end{tabular}

Аналогічне дослідження було виконано для Головинського родовища лабрадориту. Аналіз кореляційного поля для оптимального напрямку розколу та азимуту простягання тріщин (рис. 9) показав наявність певних закономірностей у групуванні значень. Виконаний кореляційний аналіз взаємозв'язку рекомендованого напрямку відколу з азимутом простягання 59 тріщин для Головинського родовища лабрадориту встановив наявність слабкого кореляційного зв’язку, який характеризується коефіцієнтом кореляції 0,382 .

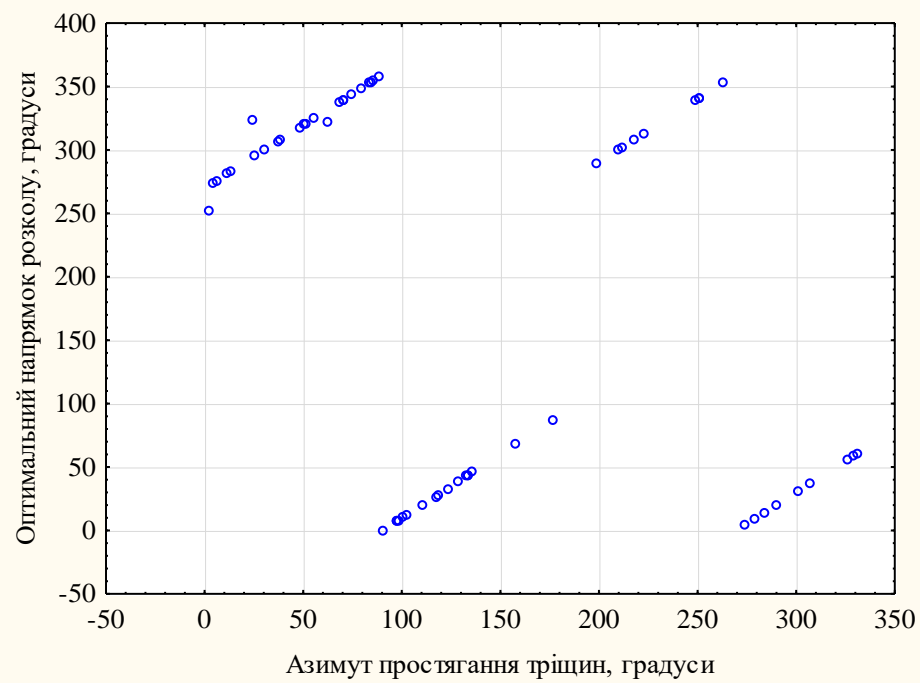

Рис. 9. Кореляційне поле для оптимального напрямку розколу та азимуту простягання тріщин для Головинського родовищца лабрадориту 
Розподіл на дві групи за результатами кластеризації дозволив виокремити основну групу 3 38 вимірювань, для якої кути падіння змінюються в межах від 0 до 60 градусів, що дозволяє зарахувати їх до субгоризонтальної системи тріщин (рис. 10). Встановлено, що коефіцієнт кореляції для субгоризонтальних тріщин становить 0,58 й це дозволяє встановити аналітичну залежність між оптимальним напрямком відколу та орієнтацією тріщин у вигляді полінома четвертого ступеня викладеного далі вигляду:

$$
\alpha_{\text {відк.onm. }}=261,4706+4,3981 \alpha_{c .2 .}-0,0916 \alpha_{c .2 .}^{2}+0,0005 \alpha_{c .2 .}^{3}-7,8044 \cdot 10^{-7} \alpha_{c .2 .}^{4},
$$

де $\alpha_{c .2 .}$ - азимут простягання субгоризонтальних тріщин (градуси).

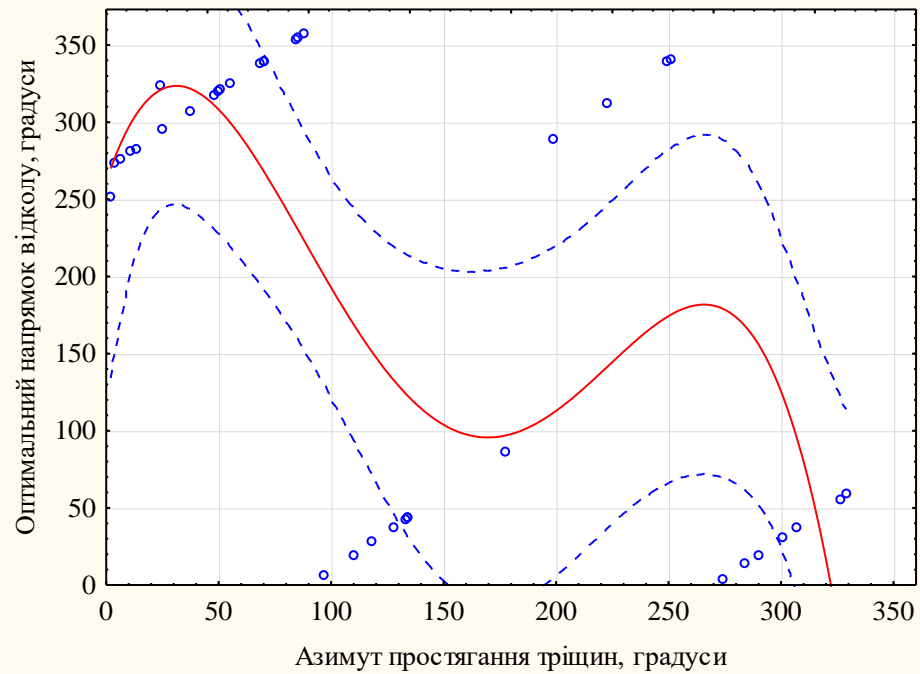

Рис. 10. Залежність напрямку оптимального відколу від азимуту простягання субгоризонтальної системи тріщцин для Головинського родовища лабрадориту

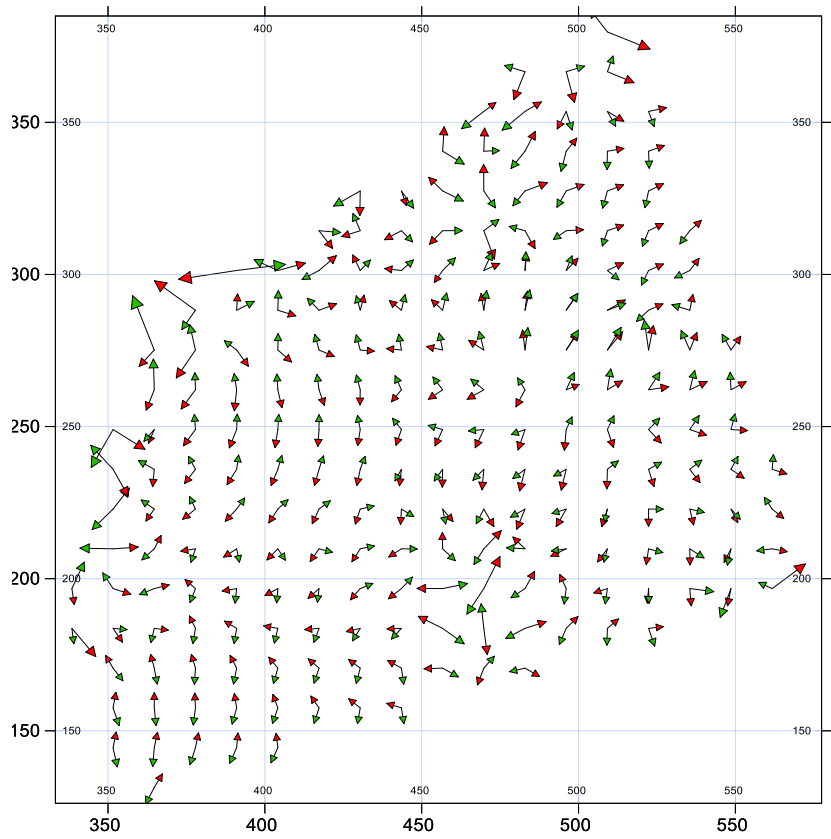

Рис. 11. Співвідношення напрямків оптимального відколу з азимутами падіння тріщин (червоний напрямок тріщин, зелений - напрямок відколу) для Головинського родовища лабрадориту

Оцінка співвідношення напрямків оптимального відколу з азимутами падіння тріщин, що виконана на основі побудови карти векторів (рис. 11), дозволяє стверджувати наявність зв'язку між зазначеними вище параметрами у західній частині, де більшість значень збігається, та наявність чітких закономірностей орієнтації в східній частині, де більшість векторів перетинаються під близькими кутами. Північна частина 
родовища характеризується певною турбулентністю напрямків, що однозначно може свідчити про складність прогнозу анізотропних властивостей у цій частині родовища.

Висновки та перспективи подальших досліджень. Проведені дослідження дали змогу розробити методику оперативного визначення вмісту та орієнтації зерен мінералів на основі виконання вимірювань цифровим мікроскопом. Реалізація такої методики дозволяє підвищити достовірність та обсяги даних, які використовуються під час визначення оптимальності технологічних рішень під час видобування та переробки декоративного каменю.

У результаті виконаних досліджень вивчено закономірності просторової мінливості напрямків оптимального відколу для родовищ лабрадоритів та габро-норитів і висунуто гіпотези щодо передумов формування анізотропності технологічних властивостей покладів декоративного каменю та їх окремих ділянок.

Встановлено аналітичну залежність у вигляді полінома четвертого ступеня для прогнозування оптимального напрямку відколу для Головинського родовища лабрадориту та доведено відсутність зв'язку оптимального напрямку відколу й орієнтації тріщинуватості для Сліпчицького родовища габро-нориту. Одержані результати значною мірою дозволяють обгрунтувати кластерну природу анізотропності технологічних властивостей окремих ділянок покладів габроїдних порід.

Результати одержаних досліджень дають змогу розробити оптимальну методику планування гірничих робіт із урахуванням анізотропії властивостей покладу декоративного каменю.

\section{Список використаної літератури:}

1. Mosch S. Optimized extraction of diceредніхіon stone blocks / S.Mosch // Environmental Earth Sciences. - 2011. Vol. 63. - P. 1911-1924.

2. Luodes $H$. Evaluation and modeling of natural stone rock quality using ground penetrating radar (GPR)/ H.Luodes, H.Sutinen // Geological Survey of Finland. Special Paper. - 2011. - Vol. 49. - P. 83-90.

3. Pershin G. Enhanced dimension stone production in quarries with complex natural jointing / G.Pershin, M.Ulyakov // Journal of Mining Science. - 2015. - Vol. 51. - P. 330-334.

4. Kalenchuk K. Characterizing block geometry in jointed rock masses / K.Kalenchuk, M.Diederichs, S.McKinnon // International Journal of Rock Mechanics and Mining Sciences. - 2006. - Vol. 43 (8). - P. 1212-1225.

5. Turanboy A. An approach to geometrical modelling of slope curves and discontinuities / A.Turanboy, M.Gökay, E. Ülker // Simulation Modelling Practice and Theory. - 2008. - Vol. 16. - P. 445-461.

6. Alade S. Modified volumetric joint count to check for suitability of granite outcrops for dimension stone production / S.Alade, O.Muriana, H.Olayinka // Journal of Engineering Science and Technology. - 2012. - Vol. 7. - P. 646-660.

7. Elci H. Rock mass block quality designation for marble production / H.Elci, N.Turk // International Journal of Rock Mechanics and Mining Sciences. - 2014. - Vol. 69. - P. 26-30.

8. Ülker $E$. Maximum volume cuboids for arbitrarily shaped in-situ rock blocks as determined by discontinuity analysis. A genetic algorithm approach / E. Ülker, A.Turanboy // Computers \& Geosciences. - 2009. - Vol. 65. - P. 1470-1480.

9. Fernández-de Arriba M. A computational algorithm for rock cutting optimization from primary blocks / M.Fernández-de Arriba // Computers and Geotechnics. - 2013. - Vol. 50. - P. 29-40.

10. Mutlutürk M. Determining the amount of marketable blocks of dimensional stone before actual extraction / M.Mutlutürk // Journal of mining science. - 2007. - Vol. 43. - P. 67-72.

11. Levytsky V.H. Decorative stone block quality control based on surface digital photogrammetry / V.H. Levytsky, R.V. Sobolevsky // Scientific Bulletin of National Mining University. - 2014. - Vol. 6. - P. 58-66.

12. Sobolevskyi R. Quality control of drilling operations for efficiency upgrading of creation of separation plane by lineage drilling / R.Sobolevskyi, V.Shlapak // Metallurgical and mining industry. - 2016. - № 2. - P. 167-173.

13. Методи підвищення якості гранітних блоків / К.Н. Ткачук, К.К. Ткачук, І.О. Фоменко, Т.В. Гребенюк// Вісник НТУУ «КПІ». Серія : Гірництво. - 2011. - № 21. - С. 103-107.

\section{References:}

1. Mosch, S. (2011), «Optimized extraction of dicepедніxion stone blocks», Environmental Earth Sciences, Vol. 63, pp. 1911-1924.

2. Luodes, H. and Sutinen, H. (2011), «Evaluation and modeling of natural stone rock quality using ground penetrating radar (GPR)», Geological Survey of Finland, Special Paper, Vol. 49, pp. 83-90.

3. Pershin, G. and Ulyakov, M. (2015), «Enhanced dimension stone production in quarries with complex natural jointing», Journal of Mining Science, Vol. 51, pp. 330-334.

4. Kalenchuk, K., Diederichs, M. and McKinnon, S. (2006), «Characterizing block geometry in jointed rock masses», International Journal of Rock Mechanics and Mining Sciences, Vol. 43 (8), pp. 1212-1225.

5. Turanboy, A., Gökay, M. and Ülker, E. (2008), «An approach to geometrical modelling of slope curves and discontinuities», Simulation Modelling Practice and Theory, Vol. 16, pp. 445-461.

6. Alade, S., Muriana, O. and Olayinka, H. (2012), «Modified volumetric joint count to check for suitability of granite outcrops for dimension stone production», Journal of Engineering Science and Technology, Vol. 7, pp. 646-660.

7. Elci, H. and Turk, N. (2014), «Rock mass block quality designation for marble production», International Journal of Rock Mechanics and Mining Sciences, Vol. 69, pp. 26-30.

8. Ülker, E. and Turanboy, A. (2009), «Maximum volume cuboids for arbitrarily shaped in-situ rock blocks as determined by discontinuity analysis. A genetic algorithm approach», Computers \& Geosciences, Vol. 65, pp. 1470-1480. 
9. Fernández-de Arriba, M. (2013), «A computational algorithm for rock cutting optimization from primary blocks», Computers and Geotechnics, Vol. 50, pp. 29-40.

10. Mutlutürk, M. (2007), «Determining the amount of marketable blocks of dimensional stone before actual extraction», Journal of mining science, Vol. 43, pp. 67-72.

11. Levytsky, V.H. and Sobolevskyj, R.V. (2014), «Decorative stone block quality control based on surface digital photogrammetry», Scientific Bulletin of National Mining University, Vol. 6, pp. 58-66.

12. Sobolevskyj, R. and Shlapak, V. (2016), «Quality control of drilling operations for efficiency upgrading of creation of separation plane by lineage drilling», Metallurgical and mining industry, No. 2, pp. 167-173.

13. Tkachuk, K.N., Tkachuk, K.K., Fomenko, I.O. and Grebenjuk, T.V. (2011), «Metody pidvyshhennja jakosti granitnyh blokiv», Visnyk NTUU «KPI», Serija Girnyctvo, No. 21, pp. 103-107.

Соболевський Руслан Вадимович - доктор технічних наук, професор кафедри маркшейдерії Державного університету «Житомирська політехніка».

Наукові інтереси:

- маркшейдерія;

- відкрита розробка родовищ корисних копалин.

Іськов Сергій Станіславович - кандидат технічних наук, доцент кафедри маркшейдерії Державного університету «Житомирська політехніка».

Наукові інтереси:

- маркшейдерія;

- відкрита розробка родовищ корисних копалин.

Камських Олександр Валерійович - кандидат технічних наук, доцент кафедри розробки родовищ корисних копалин ім. проф. М.Т. Бакка Державного університету «Житомирська політехніка».

Наукові інтереси:

- обробка природного каменю;

- відкрита розробка родовищ корисних копалин.

Шустов Олександр Олександрович - кандидат технічних наук, доцент кафедри відкритих гірничих робіт, Національний технічний університет «Дніпровська політехніка».

Наукові інтереси:

- відкриті гірничі роботи;

- видобуток блочного каменю.

Леонець Ірина Володимирівна - магістр, Державний університет «Житомирська політехніка». Наукові інтереси:

- відкриті гірничі роботи. 